\title{
The Effect of Dietary Phytase on Broiler Performance and Digestive, Bone, and Blood Biochemistry Characteristics
}

\section{mAuthor(s)}

Sousa JPL de

Albino LFT"

Vaz RGMV"I

Rodrigues KF"II

Da Silva GF"'

Renno LN"

Barros VRSM

Kaneko IN ${ }^{\mathrm{IV}}$

Instituto Federal de Educação, Ciência e Tecnologia do Tocantins, Dianópolis, Tocantins, Brazil

" Universidade Federal de Viçosa, Department of Animal Science, Viçosa, Minas Gerais, Brazi

III Universidade Federal do Tocantins, School of Veterinary Medicine and Animal Science, Department of Animal Science, Araguaína, Tocantins, Brazil

Iv Universidade Estadual de Maringá, Department of Animal Science, Maringá, Paraná, Brazil

Part of the Ph.D. thesis of the first author

\section{Mail Address}

Corresponding author e-mail address Sousa JPL de

Rua 132A, Qd45, lote 05, Setor Sul, CEP 74093-220, Goiânia, GO

E-mail: jp-zoot24@yahoo.com.br

\section{nKeywords}

Antagonism, digestible amino acid, egg components, Haugh units.

\section{ABSTRACT}

The dietary inclusion of phytase increases nutrient and energy bioavailability for broilers. The effect of phytase increases nutrients and energy bioavailability for either the objective of this experiment was to evaluate the influence of nutrient and energy reduction in diets supplemented with phytase on the performance, gastrointestinal $\mathrm{pH}$, organ and bone composition, and blood biochemistry of broilers between eight and 21 days of age. In the study, 1.120 male Cobb $500 \circledR$ broilers, with $161 \pm 1 \mathrm{~g}$ average weight, were used. At eight days of age, birds were distributed according to a completely randomized experimental design with seven treatments in a $3 \times 2+1$ factorial arrangement with eight replicates of 20 broiler each. Treatments corresponded to reduction of calcium ( $\mathrm{Ca}$ ) and phosphorus $(\mathrm{P})$, amino acids and energy, or reduction of $\mathrm{Ca}, \mathrm{P}$, amino acids and energy; supplementation or not of phytase; and a positive control treatment. Broiler fed the diet with reduced $\mathrm{Ca}$ and $\mathrm{P}$ levels and phytase supplementation presented the best performance of all groups. The diet with reduced amino acid and energy levels and phytase addition reduced gizzard and proventriculus $\mathrm{pH}$. Dietary $\mathrm{Ca}$ and $\mathrm{P}$ reduction increased relative liver and heart weights, as well as albumin blood levels. The bones of broilers fed phytase-supplemented diets presented higher ash content.

Key words: poultry production, enzymes, intestinal $\mathrm{pH}$, bone ash, calcium, available phosphorus, extra-phosporic effect

\section{INTRODUCTION}

The increasing broiler production around the world has led to the application of nutritional strategies that improve nutrient utilization. The supplementation of exogenous enzymes to corn- and soybean meal-based broiler diets allows supplying nutrient deficiencies and to reduce endogenous losses, thereby optimizing performance, particularly during early life.

The dietary supplementation of the exogenous phytase reduces nutrient variability of feedstuffs, and counteracts the antinutritional effects of phytate, increasing the accuracy of feed formulation.

Exogenous phytase is included in feed formulations not only to reduce phosphorus supplementation, but also to release minerals, particularly calcium, as well as amino acids and carbohydrates by the hydrolysis of phytate, improving nutrient utilization (Oluyinka et al., 2007; Slominski, 2011). However, nutrient utilization can also be affected by other factors, including dietary calcium, phosphorus, protein, and energy levels, intestinal $\mathrm{pH}$, environmental temperature, etc.

Dietary calcium content may negatively influence phosphorus utilization, particularly phytic phosphorus, due to the formation of insoluble complexes with calcium in the digestive tract, counteracting 
the effect of phytase, which is not able to hydrolyze such complexes (Leeson et al., 1996). Nelson et al. (1964) reported that dietary calcium levels higher than $0.70 \%$ at $\mathrm{pH} 6.0$ promote the reaction of calcium with phytic acid, resulting in calcium phytate, which precipitates and cannot be broken down by phytase, consequently reducing phosphorus bioavailability. High dietary calcium levels change the $\mathrm{pH}$ of the upper sections of the digestive tract, inactivating phytase. Phytase activity is optimal at pH between 5.0 and 6.5, and it is reduced when $\mathrm{pH}$ is lower or equal to 3.0 (Casey \& Walsh, 2004).

Broilers fed diets with low inorganic calcium and phosphorus levels have higher capacity to hydrolyze phytate than those fed high levels of these minerals (Denbow et al., 1995). Therefore, minimal calcium and phosphorus levels need to be maintained in the diet; however, their interaction should not be overlooked, particularly considering phytase activity (Qian et al., 1997).

Protein utilization and amino acid absorption may also be influenced by dietary phytic acid levels (Lehnen et al., 2011; Walk et al., 2012). These authors observed that phytic acid is a potent chelating agent. Its negative charges react with the positive charges of some amino acids (lysine, arginine, histidine), some proteins (including those involved in protein digestion, such as pepsin and trypsin), and carbohydrates $(\alpha$-amylase), forming insoluble complexes, thereby reducing their availability and digestibility (Maenz, 2001) and consequently affecting metabolism and organ biometry.

Therefore, the objective of this study was to evaluate the supply of feeds containing reduced amino acid, energy, calcium, and phosphorus levels and supplemented or not with phytase on the performance, gastrointestinal $\mathrm{pH}$, relative organ weight, bone mineral content, and blood biochemistry of broilers.

\section{MATERIALS AND METHODS}

The experiment was carried out at the Poultry Sector of the Department of Animal Science of the Federal University of Viçosa. In the study, 1,120 male Cobb $500^{\circledR}$ broilers, with $161 \pm 1 \mathrm{~g}$ average weight and between eight and 21 days of age, were used. A completely randomized experimental design in a $3 \times 2+1$ factorial arrangement ( $\mathrm{C} a$ and $\mathrm{P}$ reduction, energy and amino acid reduction, and $\mathrm{C} a, \mathrm{P}$, energy, and amino acid reduction; supplementation or not with phytase; and a positive control treatment) with eight replicates of 20 broiler each. Until eight days of age, all broilers were reared in a conventional poultry house according to the recommendations of the genetic company's (Manual, 2009). On day 8, broiler were individually weighed and distributed into 56 pens, measuring 1,5 $\mathrm{m}^{2}$ and equipped with a nipple drinker and a tube feeder each.

The increase in nutrient and energy bioavailability obtained with phytase supplementation was considered when formulating the experimental diets (Table 1). The phytase product was derived from Escherichia coli, and presented $500 \mathrm{FTU} / \mathrm{kg}$ of feed. It was added at a dose of $100 \mathrm{~g} /$ ton of feed.

Table 1 - Nutritional matrix of the bacterial phytase applied*

\begin{tabular}{lc}
\hline Nutrients and energy & 500 FTU/kg feed \\
\hline Crude protein, \% & 0.420 \\
\hline Metabolizable energy, kcal/kg & 52.00 \\
\hline Calcium, \% & 0.165 \\
\hline Phosphorus, \% & 0.150 \\
\hline Lysine, \% & 0.017 \\
\hline Methionine, \% & 0.004 \\
\hline Threonine, \% & 0.030 \\
\hline Arginine, \% & 0.030 \\
\hline *Values informed by the manufacturer &
\end{tabular}

The experimental diets were based on corn and soybean meal and were formulated to supply the nutritional requirements of male broilers, as recommended by Rostagno et al. (2011) for the starter phase.

Birds, feed offer, and feed residue were weighed per pen to calculate weight gain, feed intake, and feed conversion ratio. Mortality was also recorded to correct performance data.

On day 21, two broiler per stall, with body weight close to the average stall weight $( \pm 100 \mathrm{~g})$, were selected, identified, and had their blood collected by heart puncture. Blood was placed in test tubes, centrifuged for $5 \mathrm{~min}$ at 1,500 rpm, and the serum was then placed in duly identified Eppendorf tubes and immediately frozen until analyses. Serum calcium, phosphorus, albumin, and total protein were analyzed using specific commercial kits.

The selected birds were identified and sacrificed according to the norms of the Committee of Ethics for the Use of Animals of the Department of Animal Science of the Federal University of Viçosa process $n^{\circ}$ $76 / 2013$. Broilers were stunned, sacrificed by neck dislocation, and their gastrointestinal tract (GIT) with the digesta was aseptically removed. Before removing 
Table 2 - Composition of the experimental diet fed to broilers between 8 and 21 days of age (\% as fed)

\begin{tabular}{|c|c|c|c|c|}
\hline \multirow{2}{*}{ Ingredients } & \multirow[t]{2}{*}{ Control } & \multicolumn{3}{|c|}{ Treatment with reduced levels } \\
\hline & & Ca and $\mathrm{P}$ & $\mathrm{AA}$ and $\mathrm{ME}$ & $\mathrm{Ca}, \mathrm{P}, \mathrm{AA}$, and $\mathrm{ME}$ \\
\hline Corn & 58.81 & 60.3 & 61.39 & 62.89 \\
\hline Soybean meal & 35.04 & 34.76 & 33.70 & 33.41 \\
\hline Soybean oil & 2.30 & 1.79 & 1.07 & 0.57 \\
\hline Limestone & 1.06 & 1.15 & 1.06 & 1.15 \\
\hline Dicalcium phosphate & 1.47 & 0.66 & 1.48 & 0.66 \\
\hline Salt & 0.48 & 0.48 & 0.48 & 0.48 \\
\hline L-Lysine HCL 79\% & 0.16 & 0.17 & 0.18 & 0.19 \\
\hline DL-Methionine $99 \%$ & 0.26 & 0.26 & 0.23 & 0.23 \\
\hline L-threonine $98 \%$ & 0.03 & 0.03 & 0.01 & 0.02 \\
\hline Mineral supplement ${ }^{1}$ & 0.11 & 0.11 & 0.11 & 0.11 \\
\hline Vitamin supplement $^{2}$ & 0.11 & 0.11 & 0.11 & 0.11 \\
\hline Choline chloride $60 \%$ & 0.10 & 0.10 & 0.10 & 0.10 \\
\hline Salinomycin, $12 \%$ & 0.06 & 0.06 & 0.06 & 0.06 \\
\hline Antioxidant & 0.01 & 0.01 & 0.01 & 0.01 \\
\hline Total & 100 & 100 & 100 & 100 \\
\hline \multicolumn{5}{|c|}{ Calculated values } \\
\hline Crude protein, \% & 20.8 & 20.8 & 20.38 & 20.38 \\
\hline Metabolizable energy, kcal/kg & 3.000 & 3.000 & 2.948 & 2.948 \\
\hline Calcium, \% & 0.86 & 0.70 & 0.86 & 0.70 \\
\hline Available phosphorus, \% & 0.38 & 0.23 & 0.38 & 0.23 \\
\hline Digestible lysine, \% & 1.14 & 1.14 & 1.12 & 1.12 \\
\hline Total lysine (\%) & 1.24 & 1.24 & 1.22 & 1.22 \\
\hline Digestible methionine + cystine (\%) & 0.82 & 0.82 & 0.78 & 0.78 \\
\hline Total methionine + cysteine, $\%$ & 0.90 & 0.90 & 0.86 & 0.86 \\
\hline Digestible threonine (\%) & 0.74 & 0.74 & 0.71 & 0.71 \\
\hline Total threonine, \% & 0.85 & 0.85 & 0.81 & 0.81 \\
\hline Digestible arginine, $\%$ & 1.31 & 1.31 & 1.28 & 1.28 \\
\hline
\end{tabular}

Supplement $/ \mathrm{kg}$ feed: ' Manganese $77.0 \mathrm{mg}$; iron - $55.0 \mathrm{mg}$; zinc - $71.5 \mathrm{mg}$; copper - $11.0 \mathrm{mg}$; cobalt- $1.0 \mathrm{mg}$; iodine- $1.1 \mathrm{mg}$; selenium- 0.33 mg. ${ }^{2}$ Vitamin A - $8250 \mathrm{UI}$; Vitamin D3 - 2090 Ul; Vitamin E - 31 Ul; Vitamin B1 - 2.2 mg; Vitamin B6 - 3.08 mg; pantothenic acid - 11.0 mg; biotin- 0.077 mg; Vitamin K3 - 1.65 mg; folic acid - $0.770 \mathrm{mg}$; nicotinic acid - $33.0 \mathrm{mg}$; Vitamin B12 - $0.013 \mathrm{mg}$

the digesta, the proventriculus, gizzard, duodenum (from the caudal end of the gizzard until the end of the duodenal loop), jejunum (from the end of the duodenum until Meckel's diverticulum), ileum (from Meckel's diverticulum until the ileal-cecal junction), and the ceca were isolated to prevent the digesta from mixing. Then, the $\mathrm{pH}$ was measured sing a digital pHmeter gently introducing the sterilized fine tip of the glass electrode in each GIT section. As recommended by Pang \& Applegate (2007), pH was measured twice in each section and the average of the two measurements was used for the statistical analysis. Subsequently, the intestine, gizzard, liver, heart, bursa, and spleen were removed. The intestine was measured using a measuring tape.
The left tibia bone was collected, dehydrated in ethanol, and de-fatted in petroleum ether in Soxhlet apparatus for four hours. Bones were then burnt in a muffle at $600^{\circ} \mathrm{C}$ to determine ash content, according to Gardiner et al. (1961). Ashes were then used to prepare a mineral solution by dissolving the ashes by digestion on a heated plate for four hours at $200^{\circ} \mathrm{C}$. Calcium content in the ashes was determined by atomic absorption spectrophotometry and phosphorus content was determined by colorimetric spectrophotometry, according to the methods described by Detmann.

Data were submitted to Shapiro Wilk's normality test and then to analysis of variance using the General Linear Model (PROC GLM) procedures of SAS statistical package (1998). Means were compared by orthogonal contrasts. Each contrast was independently tested by the $\mathrm{F}$ test a $10 \%$ probability level.

The following orthogonal contrasts were analyzed: contrast $C_{1}$, comparing diets with reduced calcium (Ca) and phosphorus $(P)$ levels supplemented or not with phytase; contrast $C_{2}$, comparing diets with reduced amino acid (AA) and energy (ME) contents supplemented or not with phytase; contrast $C_{3}$ comparing diets with reduced $A A, M E$, $\mathrm{Ca}$ and $\mathrm{P}$ levels supplemented or not with phytase; contrast $C_{4^{\prime}}$ comparing the positive-control diet and the diet with reduced $A A, M E, C a$ and $P$ levels and not supplemented with phytase; contrast $C_{5}$, comparing the positive-control diet and the diet with reduced $A A, M E, C a$ and $P$ levels and supplemented with phytase, and contrast $C_{6}$, comparing the diets with reduced nutrient levels supplemented or not with phytase.

\section{RESULTS}

Contrast $C_{1}$ shows that the performance of broilers fed the diet with reduced $\mathrm{Ca}$ and $\mathrm{P}$ levels and supplemented with phytase was better $(P<0.01)$ than those fed the same diet with no phytase supplementation, with improvements of 4.40, 11.04, and $7.14 \%$ in feed intake (FI), weight gain (WG), and feed conversion ratio (FCR), respectively (Table 3 ). 
Table 3 - Performance of broilers fed starter diets (8-21 days of age) with reduced nutrient and energy levels and supplemented or not with phytase.

\begin{tabular}{|c|c|c|c|c|c|c|c|c|c|c|c|c|c|c|}
\hline \multirow{4}{*}{ Parameter } & \multicolumn{7}{|c|}{ Treatment with reduced levels } & \multirow{3}{*}{$\left(\mathrm{CV}^{5}(\%)\right.$} & & & & & & \\
\hline & \multirow[t]{2}{*}{$\mathrm{CP}^{1}$} & \multicolumn{2}{|c|}{$\mathrm{Ca}$ and $\mathrm{P}^{2}$} & \multicolumn{2}{|c|}{$\mathrm{AA}$ and $\mathrm{ME}^{3}$} & \multicolumn{2}{|c|}{$\mathrm{Ca}, \mathrm{P}, \mathrm{AA}$, and $\mathrm{ME}^{4}$} & & \multicolumn{6}{|c|}{ Orthogonal contrasts ${ }^{6}$} \\
\hline & & \multirow[t]{2}{*}{$\begin{array}{c}\text { W/o } \\
\text { phytase }\end{array}$} & \multirow[t]{2}{*}{$\begin{array}{l}\text { With } \\
\text { phytase }\end{array}$} & \multirow[t]{2}{*}{$\begin{array}{c}\text { W/o } \\
\text { phytase }\end{array}$} & \multirow[t]{2}{*}{$\begin{array}{l}\text { With } \\
\text { phytase }\end{array}$} & \multirow[t]{2}{*}{$\begin{array}{c}\text { W/o } \\
\text { phytase }\end{array}$} & \multirow[t]{2}{*}{$\begin{array}{c}\text { With } \\
\text { phytase }\end{array}$} & & & & & & & \\
\hline & & & & & & & & & $C_{1}$ & $C_{2}$ & $C_{3}$ & $\mathrm{C}_{4}$ & $C_{5}$ & $\mathrm{C}_{6}$ \\
\hline $\mathrm{Fl}(\mathrm{g})$ & 1085 & 1064 & 1113 & 1100 & 1094 & 1064 & 1110 & 3.01 & * & NS & * & NS & NS & NS \\
\hline WG (g) & 782 & 725 & 815 & 765 & 763 & 684 & 741 & 4.18 & * & NS & * & * & NS & * \\
\hline $\mathrm{FCR}(\mathrm{g} / \mathrm{g})$ & 1.390 & 1.471 & 1.366 & 1.439 & 1.437 & 1.559 & 1.503 & 4.46 & * & NS & $* * *$ & * & NS & * \\
\hline \multicolumn{15}{|c|}{ 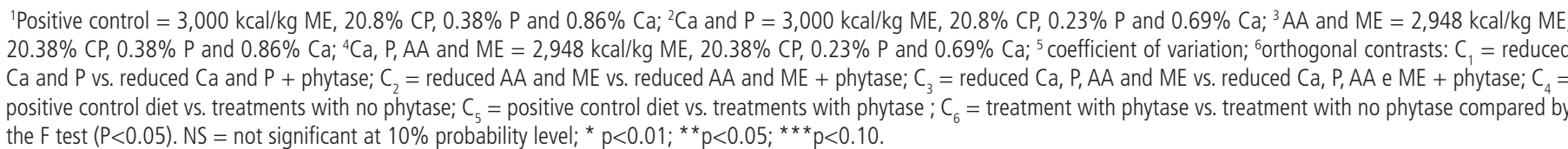 } \\
\hline
\end{tabular}

The contrast comparing the supplementation or not of phytase of diets with reduced $\mathrm{Ca}, \mathrm{P}, \mathrm{AA}$, and ME level (Contrast $C_{3}$ ) indicated that broilers receiving phytase presented better $\mathrm{FI}(\mathrm{p}<0.01)$, WG $(\mathrm{p}<0.01)$, and FCR $(p<0.10)$, which improved 4.14, 7.69, and $3.59 \%$, respectively. Interestingly, the improvement in performance with phytase supplementation was more evident in broilers fed reduced $\mathrm{Ca}$ and $\mathrm{P}$ levels (contrasts $\mathrm{C}_{1}$ and $\mathrm{C}_{3}$ ).

When the positive-control diet was compared with the diets supplemented with phytase (contrast $C_{5}$ ), it was observed that the dietary reduction of nutrients and energy did not influence broiler performance ( $p>0.05)$. On the other hand, broilers fed the positive-control diet presented better $\mathrm{FI}$ and WG $(p<0.01)$ compared with those fed the diet with reduced nutrient and energy levels and no phytase supplementation (contrast $C_{4}$ ).
When the diets with reduced nutrient and energy levels and supplemented or not with phytase were compared (contrast $C_{6}$ ), phytase supplementation improved WG and FCR $(p<0.01)$.

The addition of phytase to the reduced $A A$ and $M E$ diet (contrast $\mathrm{C}_{2}$ ) reduced the $\mathrm{pH}$ of the proventriculus $(p<0.10)$ and of the gizzard $(p<0.01)$ in 11.41 and $19.54 \%$, respectively (Table 4 ).

The $\mathrm{pH}$ of the proventriculus (contrast $\mathrm{C}_{4}$ ) and of the gizzard (contrast $C_{6}$ ) increased $(p<0.10)$ when phytase was added to the diets.

There was no influence of treatments on gizzard relative weight (Table 5). However, when the phytase supplementation was evaluated in reduced $\mathrm{Ca}$ and $\mathrm{P}$ diets (contrast $\left.C_{1}\right)$, liver $(p<0.10)$ and heart $(P<0.01)$ relative weights increased in 9.06 and $13.33 \%$ in broilers fed the diet with no phytase addition.

Table 4 - Gastrointestinal tract pH of broilers fed starter diets (8-21 days of age) with reduced nutrient and energy levels and supplemented or not with phytase.

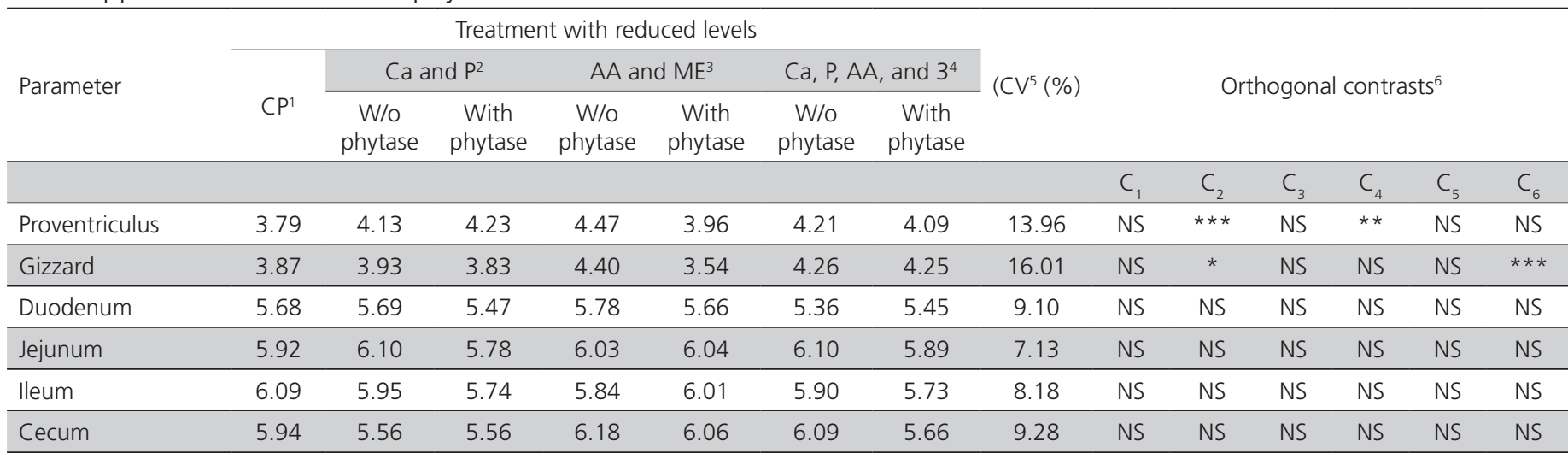

${ }^{1}$ Positive control = 3,000 kcal $/ \mathrm{kg} \mathrm{ME}, 20.8 \% \mathrm{CP}, 0.38 \% \mathrm{P}$ and $0.86 \% \mathrm{Ca} ; 2 \mathrm{Ca}$ and P =3,000 kcal $/ \mathrm{kg} \mathrm{ME}, 20.8 \% \mathrm{CP}, 0.23 \% \mathrm{P}$ and $0.69 \% \mathrm{Ca} ; 3 \mathrm{AA}$ and ME $=2,948 \mathrm{kcal} / \mathrm{kg} \mathrm{ME}$, $20.38 \%$ CP, $0.38 \%$ P and $0.86 \%$ Ca; 4 Ca,, , AA and ME $=2,948 \mathrm{kcal} / \mathrm{kg} \mathrm{ME}, 20.38 \%$ CP, 0.23\% P and 0.69\% Ca; 5 coefficient of variation; ${ }^{6}$ orthogonal contrasts: $C_{1}=$ reduced $C a$ and $P$ vs. reduced $C a$ and $P+$ phytase; $C_{2}=$ reduced $A A$ and $M E$ vs. reduced $A A$ and $M E+$ phytase; $C_{3}=$ reduced $C a, P, A A$ and $M E$ vs. reduced $C a, P, A A$ e $M E+$ phytase; $C_{4}=$ positive control diet vs. treatments with no phytase; $C 5=$ positive control diet vs. treatments with phytase ; $C_{6}=$ treatment with phytase vs. treatment with no phytase compared by the $F$ test $(p<0.05)$. NS = not significant at $10 \%$ probability level; ${ }^{*} p<0.01 ;{ }^{* *} p<0.05 ;{ }^{* * *} p<0.10$. 
Table 5 - Organ biometrics of broilers fed starter diets (8-21 days of age) with reduced nutrient and energy levels and supplemented or not with phytase.

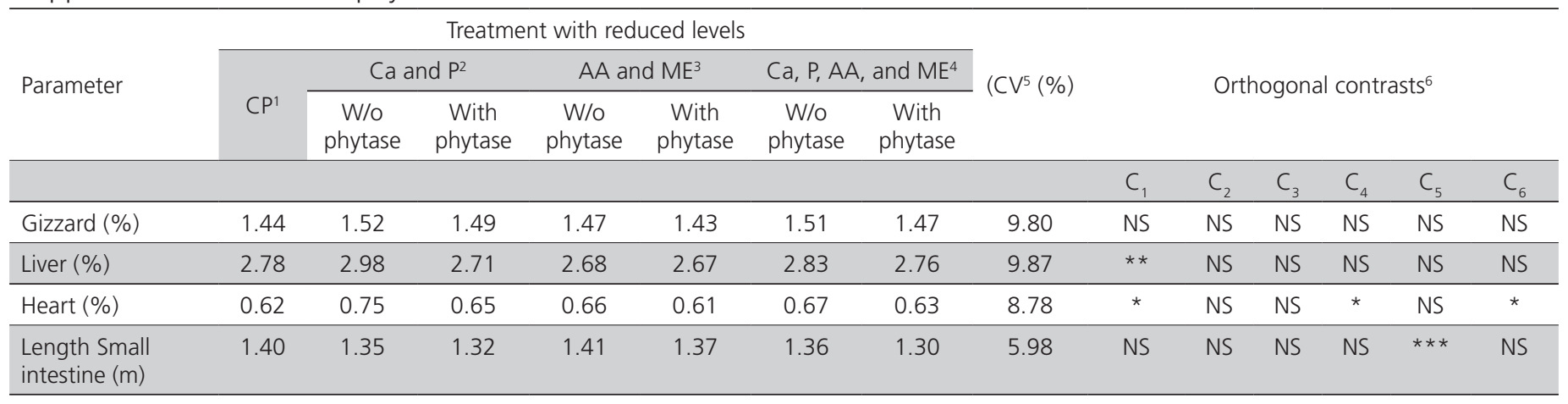

${ }^{1}$ Positive control $=3,000 \mathrm{kcal} / \mathrm{kg} \mathrm{ME}, 20.8 \% \mathrm{CP}, 0.38 \% \mathrm{P}$ and $0.86 \% \mathrm{Ca} ; 2 \mathrm{Ca}$ and $\mathrm{P}=3,000 \mathrm{kcal} / \mathrm{kg} \mathrm{ME}, 20.8 \% \mathrm{CP}, 0.23 \% \mathrm{P}$ and $0.69 \% \mathrm{Ca} ; 3 \mathrm{AA}$ and $\mathrm{ME}=2,948 \mathrm{kcal} / \mathrm{kg} \mathrm{ME}$, $20.38 \% \mathrm{CP}, 0.38 \% \mathrm{P}$ and $0.86 \% \mathrm{Ca} ; 4 \mathrm{Ca}, \mathrm{P}, \mathrm{AA}$ and $\mathrm{ME}=2,948 \mathrm{kcal} / \mathrm{kg} \mathrm{ME}, 20.38 \% \mathrm{CP}, 0.23 \% \mathrm{P}$ and $0.69 \% \mathrm{Ca} ; 5$ coefficient of variation; ${ }^{6}$ orthogonal contrasts: $\mathrm{C}_{1}=\mathrm{reduced}$ $C a$ and $P$ vs. reduced $C a$ and $P+$ phytase; $C_{2}=\operatorname{reduced} A A$ and $M E$ vs. reduced $A A$ and $M E+$ phytase; $C_{3}=$ reduced $C a, P, A A$ and $M E$ vs. reduced $C a, P, A A$ e $M E+$ phytase; $C_{4}=$ positive control diet vs. treatments with no phytase; $C 5=$ positive control diet vs. treatments with phytase $; C_{6}=$ treatment with phytase vs. treatment with no phytase compared by the F test $(p<0.05)$. NS $=$ not significant at $10 \%$ probability level; ${ }^{*} p<0.01 ;{ }^{* *} p<0.05 ;{ }^{* * *} p<0.10$

Heart relative weight increased $(p<0.01)$ when broilers were fed the reduced nutrient diets with no phytase additions (contrasts $\mathrm{C}_{4}$ and $\mathrm{C}_{6}$ ).

Intestinal length was different $(p<0.10)$ in broiler fed diets containing phytase, as shown in contrast $C_{5}$.

Tibial ash content $(p<0.01, \%$ DM) and phosphorus deposition ( $p<0.10 ; \%$ DM) increased 9.53 and $13.56 \%$, respectively, when broilers were fed the diet with reduced $\mathrm{Ca}$ and $\mathrm{P}$ levels supplemented with phytase (contrast $C_{1}$; Table 6 ).

Tibial ash content (\%DM) was significantly different $(p<0.05)$, as shown by contrast $C_{3}$. Broilers were fed the reduced nutrient diets containing phytase than those fed the positive-control diet (contrasts $C_{4}$ and $\mathrm{C}_{5}$ ) presented higher tibial ash content (\% DM). In addition, when the positive-control diet was compared with the reduced $\mathrm{Ca}$ and $\mathrm{P}$ diet containing phytase, there was higher $\mathrm{Ca}$ and $\mathrm{P}$ deposition (\% DM), with 5.32 and $13.77 \%$, respectively. Contrast $C_{5}$ did not reveal any differences $(p>0.05)$ in tibial $\mathrm{Ca}$ or $\mathrm{P}$ content (\% DM).

As determined by contrast $\mathrm{C}_{6^{\prime}}$ tibial $\mathrm{Ca}$ and $\mathrm{P}$ deposition (\% DM) and $\mathrm{Ca}$ to $\mathrm{P}$ ratio were higher $(p<0.05)$ when the diets were supplemented with phytase.

Blood albumin levels ( $\mathrm{g} / \mathrm{dL}$ ) were higher $(p<0.10)$ in birds in the treatments with no phytase supplementation, as shown by contrasts $C_{1}$ and $C_{2}$ (Table 7).

Blood $P$ levels $(\mathrm{mg} / \mathrm{dL})$ were different $(p<0.10)$ as determined by contrasts $C_{3}$ and $C_{4}$ as well as $C$ a/P ratio detected by $C_{1}(p<0.01), C_{3}(p<0.01)$ and $C_{4}(p<0.05)$.

Table 6 - Bone mineral content of broilers fed starter diets (8-21 days of age) with reduced nutrient and energy levels and supplemented or not with phytase.

\begin{tabular}{|c|c|c|c|c|c|c|c|c|c|c|c|c|c|c|}
\hline \multirow{3}{*}{ Parameter } & \multicolumn{7}{|c|}{ Treatment with reduced levels } & \multirow{3}{*}{$\begin{array}{c}\left(\mathrm{CV}^{5}\right. \\
(\%)\end{array}$} & & & & & & \\
\hline & \multirow[b]{2}{*}{$C P^{1}$} & \multicolumn{2}{|c|}{$\mathrm{Ca}$ and $\mathrm{P}^{2}$} & \multicolumn{2}{|c|}{$\mathrm{AA}$ and $\mathrm{ME}^{3}$} & \multicolumn{2}{|c|}{$\mathrm{Ca}, \mathrm{P}, \mathrm{AA}$, and $\mathrm{ME}^{4}$} & & \multicolumn{6}{|c|}{ Orthogonal contrasts ${ }^{6}$} \\
\hline & & $\begin{array}{c}\text { W/o } \\
\text { phytase }\end{array}$ & $\begin{array}{c}\text { With } \\
\text { phytase }\end{array}$ & $\begin{array}{c}\text { W/o } \\
\text { phytase }\end{array}$ & $\begin{array}{c}\text { With } \\
\text { phytase }\end{array}$ & $\begin{array}{c}\text { W/o } \\
\text { phytase }\end{array}$ & $\begin{array}{c}\text { With } \\
\text { phytase }\end{array}$ & & & & & & & \\
\hline & & & & & & & & & $\mathrm{C}_{1}$ & $\mathrm{C}_{2}$ & $\mathrm{C}_{3}$ & $\mathrm{C}_{4}$ & $C_{5}$ & $\mathrm{C}_{6}$ \\
\hline Dry matter (\%) & 94.33 & 93.54 & 93.97 & 91.98 & 92.60 & 92.36 & 92.18 & 1.56 & ** & NS & NS & * & $* *$ & NS \\
\hline Ashes (\% DM) & 51.22 & 46.48 & 50.92 & 44.94 & 46.87 & 46.96 & 49.85 & 4.86 & * & NS & * & * & * & NS \\
\hline $\mathrm{P}(\% \mathrm{DM})$ & 12.02 & 12.25 & 13.94 & 10.83 & 10.80 & 10.69 & 10.44 & 5.68 & $* * *$ & NS & NS & NS & NS & * \\
\hline Ca (\% DM) & 26.66 & 27.31 & 28.16 & 26.94 & 26.94 & 25.48 & 26.21 & 4.78 & NS & NS & NS & NS & NS & * \\
\hline $\mathrm{Ca} / \mathrm{P}(\mathrm{DM})$ & 2.22 & 2.23 & 2.02 & 2.49 & 2.49 & 2.38 & 2.51 & 7.10 & NS & NS & NS & NS & NS & $\star *$ \\
\hline
\end{tabular}

${ }^{1}$ Positive control = 3,000 kcal $/ \mathrm{kg} \mathrm{ME}, 20.8 \% \mathrm{CP}, 0.38 \% \mathrm{P}$ and $0.86 \% \mathrm{Ca} ; 2 \mathrm{Ca}$ and $\mathrm{P}=3,000 \mathrm{kcal} / \mathrm{kg} \mathrm{ME}, 20.8 \% \mathrm{CP}, 0.23 \% \mathrm{P}$ and $0.69 \% \mathrm{Ca} ; 3 \mathrm{AA}$ and $\mathrm{ME}=2,948 \mathrm{kcal} / \mathrm{kg} \mathrm{ME}$, $20.38 \%$ CP, $0.38 \%$ P and 0.86\% Ca; 4Ca, P, AA and ME = 2,948 kcal/kg ME, 20.38\% CP, 0.23\% P and 0.69\% Ca; 5 coefficient of variation; ${ }^{6}$ orthogonal contrasts: $C_{1}=$ reduced $C a$ and $P$ vs. reduced $C a$ and $P+$ phytase; $C_{2}=$ reduced $A A$ and $M E$ vs. reduced $A A$ and $M E+$ phytase; $C_{3}=$ reduced $C a, P, A A$ and $M E$ vs. reduced $C a, P, A A$ e $M E+$ phytase; $C_{4}=$ positive control diet vs. treatments with no phytase; $C 5=$ positive control diet vs. treatments with phytase ; $C_{6}=$ treatment with phytase vs. treatment with no phytase compared by the $\mathrm{F}$ test $(\mathrm{p}<0.05)$. NS = not significant at $10 \%$ probability level; ${ }^{*} p<0.01 ;{ }^{* *} p<0.05 ;{ }^{* * *} p<0.10$. 
Table 7 - Blood biochemistry of broilers fed starter diets (8-21 days of age) with reduced nutrient and energy levels and supplemented or not with phytase.

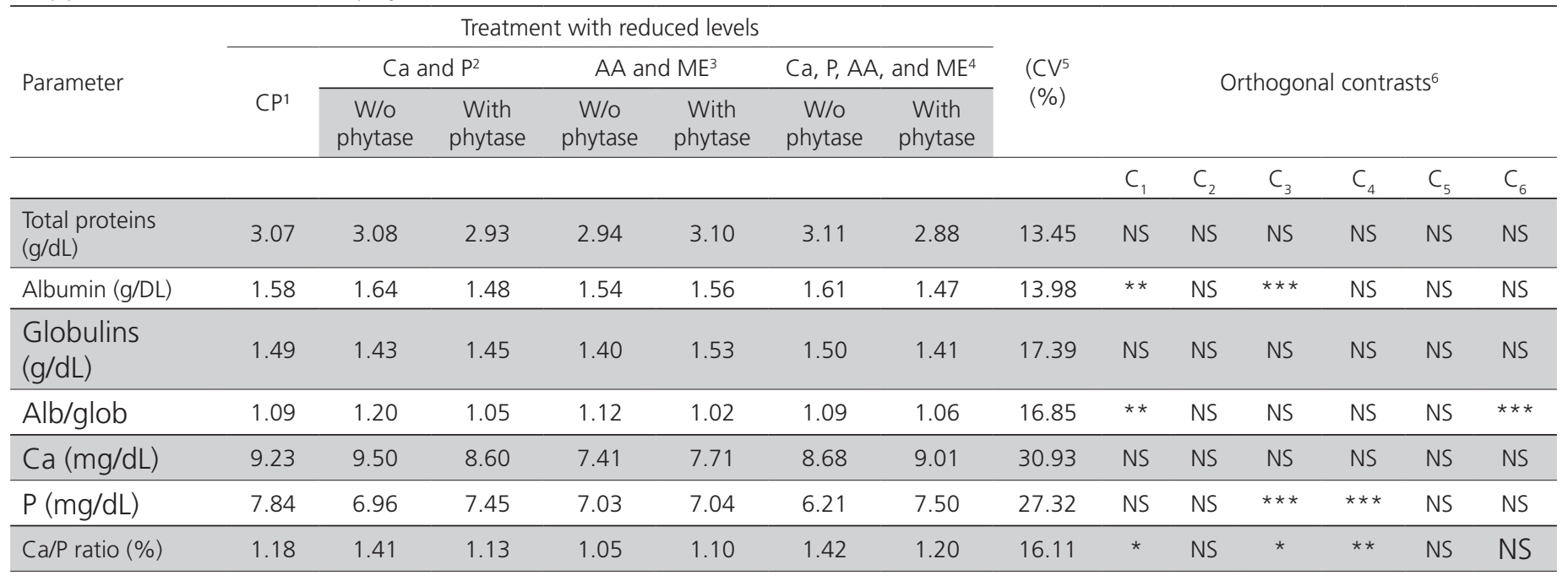

${ }^{1}$ Positive control = 3,000 kcal $/ \mathrm{kg} \mathrm{ME}, 20.8 \% \mathrm{CP}, 0.38 \% \mathrm{P}$ and $0.86 \% \mathrm{Ca} ; 2 \mathrm{Ca}$ and $\mathrm{P}=3,000 \mathrm{kcal} / \mathrm{kg} \mathrm{ME}, 20.8 \% \mathrm{CP}, 0.23 \% \mathrm{P}$ and $0.69 \% \mathrm{Ca} ; 3 \mathrm{AA}$ and ME $=2,948 \mathrm{kcal} / \mathrm{kg} \mathrm{ME}$, $20.38 \% \mathrm{CP}, 0.38 \% \mathrm{P}$ and $0.86 \% \mathrm{Ca} ; 4 \mathrm{Ca}, \mathrm{P}, \mathrm{AA}$ and $\mathrm{ME}=2,948 \mathrm{kcal} / \mathrm{kg} \mathrm{ME}, 20.38 \% \mathrm{CP}, 0.23 \% \mathrm{P}$ and $0.69 \%$ Ca; 5 coefficient of variation;

${ }^{6}$ Orthogonal contrasts: $C_{1}=$ reduced $C a$ and $P$ vs. reduced $C$ and $P+$ phytase; $C_{2}=$ reduced $A A$ and $M E$ vs. reduced $A A$ and $M E+$ phytase; $C_{3}=$ reduced $C a, P, A A$ and $M E$ vs. reduced $C a, P, A A$ e $M E+$ phytase; $C_{4}=$ positive control diet vs. treatments with no phytase; $C 5=$ positive control diet vs. treatments with phytase ; $C_{6}=$ treatment with phytase vs. treatment with no phytase compared by the $\mathrm{F}$ test $(p<0.05)$. NS = not significant at $10 \%$ probability level; ${ }^{*} p<0.01 ;{ }^{* *} p<0.05 ;{ }^{* * *} p<0.10$.

\section{DISCUSSION}

Literature studies show differences in the capacity of phytase of releasing $P$ from phytate due to influence of dietary Ca content. The better performance of broilers fed reduced $\mathrm{Ca}$ and $\mathrm{P}$ levels and phytase obtained in the present study suggest that phytase promoted better $\mathrm{Ca}$ and $\mathrm{P}$ utilization. This is consistent with the results of Powell et al. (2011), who found that it phytase is used more efficiently when dietary Ca levels are reduced.

These results also confirm that the use of enzymes in corn- and soybean meal-based broiler diets promote better performance $(p<0.01)$ by breaking down the antinutritional factors present in the cell wall of plants (Graham et al., 2002), and hence, better nutrient absorption and animal performance (Costa Leite et al., 2011; Powell et al., 2011; Walk et al., 2012).

On the other hand, Alvarenga et al. (2011) obtained lower broiler weight gain when the diets contained phytase. Also, in his review, Slominsk (2011) found little effect of phytase supplementation on performance and the utilization of energy and amino acid utilization in broilers. These differences may be related to the different source of phytase currently available in the market (Elkhalil et al., 2007). The positive results obtained in the present study may be possibly attributed to a better efficiency phytase derived from $E$. coli.
Another possible cause of the improved responses may have been the lower dietary $C$ a levels. Inadequate dietary Ca levels may impair $\mathrm{Ca}, \mathrm{P}, \mathrm{Zn}$, and $\mathrm{Mg}$ absorption. However, $\mathrm{Ca}$ reduction in phytasesupplemented diets must be proportional do total phosphorus (tP) reduction in order to maintain the required Ca:P ratio. According to Pereira et al. (2012), the inclusion of phytase in feed formulation matrices provides economic and environmental benefits in broiler production.

The lower $\mathrm{pH}$ values observed in the gizzard $(p<0.01)$ and the proventriculus $(p<0.10)$ of broilers fed the reduced nutrient and energy level and no phytase can be attributed to the attempt of birds to balance nutrient intake and energy utilization to supply their requirements.

Phytate is hydrolyzed mainly in the upper gastric tract (proventriculus and gizzard), where the $\mathrm{pH}$ favors the action of phytase and its substrate is more water soluble (Selle \& Ravidran, 2007). According to Penz et al. (1993), GIT pH reduction enhances enzyme activity, thereby increasing dietary nutrient absorption and improving animal performance.

The observed increase in liver $(p<0.10)$ and heart $(p<0.01)$ relative weights in the broilers fed diets with reduced $\mathrm{Ca}$ and $\mathrm{P}$ levels and no phytase supplementation is probably due to low phosphorus supply. Heart hypertrophy (increase of heart muscle mass beyond the usual limit) may be caused by 
hypophosphatemia due to low phosphorus supply (Rosário et al., 2004; Temprano et al., 2004). Hearts with hypertrophy usually present reduced contraction due to reduced myosin ATPase activity and lower cyclic adenosine monophosphate (CAMP), which may result from hypophosphatemia. This may lead to heart failure, reducing the systolic volume and increasing myocardial fiber diameter (Riedesel, 2006).

Low ATP production stimulates the synthesis of liver enzymes, increasing liver volume (Reis et al., 1999). Oliveira et al. (2009) observed reduced liver and heart relative weights when broilers were fed diets with $70 \%$ reduction in non-phytic phosphorus level.

The increase in tibial ash $(p<0.01, \% D M)$ and phosphorus deposition ( $p<0.10 ; \% D M)$ determined in broilers fed the diet with phytase addition reduced $C a$ and $P$ levels and in ash content $(p<0.05)$ in broilers fed the reduced $C a, P, A A$, and ME diet with phytase supplementation was expected, because phytase increases the release of phosphorus and other minerals from the feedstuffs. According to Nelson \& Walker (1964) and Pereira et al. (2012), bone ash content is the most efficient parameter to estimate the amount of phosphorus released by phytase in corn- and soybean meal-based diets.

Geraldo et al. (2006) found $1.88 \%$ reduction in tibial ash content for each $1 \%$ increase in dietary calcium levels. The dietary supplementation of phytase allows reducing dietary available phosphorus in $0.15 \%$ and Ca in $0.15 \%$ (Gomide et al., 2011). Consistent with the present study, Schoulten et al. (2003) observed that reduced $\mathrm{P}$ diets supplemented with phytase allowed reducing $\mathrm{Ca}$ requirements to lower values than those present in nutritional tables, but recommended that dietary $\mathrm{Ca}$ reduction should be proportional to total $\mathrm{P}$ reduction, maintaining adequate $\mathrm{Ca}$ to $\mathrm{P}$ ratio, as also mentioned by Qian et al. (1997).

In the present experiment, average total protein levels in the blood ranged between 2.88 (reduced $\mathrm{Ca}, \mathrm{P}, \mathrm{AA}$, and ME and no phytase) and $3.11 \mathrm{mg} / \mathrm{dL}$ (reduced $\mathrm{Ca}, \mathrm{P}, \mathrm{AA}$, and $\mathrm{ME}$ and with phytase) are below those considered normal $(3.6 \mathrm{mg} / \mathrm{dL})$. According to Viveiros et al. (2002), total protein level in the serum may be reduced in case of malnutrition or low intestinal absorption of nutrients, but the treatments applied in the present study did not cause any of these conditions.

Blood Ca level (mg/dL) was not influenced ( $p>0.10)$ by the applied treatments, possibly because $\mathrm{Ca}$ homeostasis in the extracellular fluid is maintained by the joint effects of the parathyroid hormone (PTH), calcitonin, and 1,25 di-hydroxy vitamin $\mathrm{D}\left(1,25(\mathrm{OH})_{2} \mathrm{D}_{3}\right)$ in the intestines, kidneys, and bone. Those hormones regulate $\mathrm{Ca}$ flow between these organs and the extracellular fluid, resulting in less than $5 \%$ variation in Ca blood levels under normal circumstances, and only occurs when hormonal mechanisms fail, secondarily to reduced intestinal absorption (Macari et al., 2002). In the present study, mean Ca serum values were lower than those obtained by Vieites et al. (2011), of 6.72 and $6.89 \mathrm{mg} / \mathrm{dL}$.

The higher albumin values $(p<0.10)$ found in broilers fed reduced nutrient and energy levels and no phytase supplementation are considered normal (1.6-2.0 g/dL; Reece \& Swenson, 2006).

Albumins are synthesized in the liver and are very abundant in blood plasma, where they play an essential role in the maintenance of the osmotic pressure (Junqueira \& Carneiro, 2011). Differences in serum albumin levels, according to Macari et al. (2002) are probably due to acid-base imbalance (metabolic acidosis or alkalosis), because of the buffering action of these proteins that capture or donate $\mathrm{H}^{+}$ions by their carboxylic terminals ( $\mathrm{COOH}$ or $\left.\mathrm{COO}^{-}\right)$attempting to reestablish normal blood $\mathrm{pH}$. This was possibly the case in the present study, and this hypothesis is corroborated by the increase in liver relative weight,

Consistent with this result, the $\mathrm{Ca} / \mathrm{P}$ ratios presented in contrasts $\mathrm{C} 1, \mathrm{C} 3$, and $\mathrm{C} 4$ show higher concentration of $\mathrm{P}$ relative to $\mathrm{Ca}$, causing osmotic pressure imbalance (Reece \& Swenson, 2006). This difference in the Ca/P ratio is mainly due to $P$ variation $(\mathrm{mg} / \mathrm{dL})$, which was different in contrast $C 3$ and $C 4(p<0.10)$. According to Vargas Jr. et al. (2003), the Ca to $P$ ratio must be constant; any imbalance may affect body functions.

The difference in the glob/alb ratios obtained in contrasts C 1 and C 6 may be explained by the reduction of this ratio in the treatments with phytase, as shown in the contrasts between treatments with or without phytase and $\mathrm{Ca}$ and $\mathrm{P}$ reduction (contrast $\mathrm{C} 1$ ). This was caused by variations in the albumin fraction, demonstrating the effect of $\mathrm{Ca}$ and $\mathrm{P}$ reduction on the metabolism of the liver, which is the only site of albumin synthesis.

The diet with reduced amino acid and energy levels and phytase addition reduced gizzard and proventriculus $\mathrm{pH}$. Dietary $\mathrm{Ca}$ and $\mathrm{P}$ reduction increased relative liver and heart weights, as well as albumin blood levels. The bones of broilers fed phytase-supplemented diets presented higher ash content. The results of the present study suggest that broiler nutritional requirements need to be reevaluated when the diet is supplemented with phytase. 


\section{REFERENCES}

Alvarenga RR, Nagata AK, Rodrigues PB, Zangeronimo MG, Pucci LEA, Hespanhol R. Adição de fitase em rações com diferentes níveis de energia metabolizável, proteína bruta e fósforo disponível para frangos de corte de 1 a 21 dias. Ciência Animal Brasileira 2011;12(4):602-609.

Casey, A.; Walsh, G. Identification and characterization of a phytase of potential commercial interest. Journal of Biotechnology 2004;110(3):313-322

Costa Leite PRS, Leandro NSM, Stringhini JH, Café, MB, Gomes NA, Jardim Filho M. Desempenho de frangos de corte e digestibilidade de rações com sorgo ou milheto e complexo enzimático. Pesquisa agropecuária Brasileira 2011;46(3):280-286

Denbow DM, Ravindran V, Kornegay YIZ, Hulet RM. Improving phosphorus availability in soybean meal for broilers by supplemental phytase. Poultry Science 1995;74(11):1831-1842.

Detmann E, Souza MA, Valadares Filho SC, Queiroz AC, Beterchielli TT, Saliba EOS, Cabral LS, Santos Pina D, Ladeira MM, Azevedo JAG. Métodos para análise de alimentos. Visconde do Rio Branco: Universidade Federal de Viçosa; 2012.

Elkhalil EAl, Manner K, Borriss R, Simon O. In vitro and in vivo characteristics of bacterial phytases and their efficacy in broiler chickens. British Poultry Science 2007;48(1):64-70

Geraldo A, Bertechini AG, De Brito JAG, Kato RK, Fassani EJ. Níveis de cálcio e granulometria do calcário para frangas de reposição no período de 3 a 12 semanas de idade. Revista Brasileira de Zootecnia 2006;36(1):113118.

Gomide ME, Rodrigues PB, Beterchini AG, Freitas TF, Fassani EJ, Reis MP, Rodrigues NEB, Almeida EC. Rações com níveis reduzidos de proteína bruta, cálcio e fósforo com fitase e aminoácidos para frangos de corte. Revista Brasileira de Zootecnia 2011;40(11):2405-2414

Graham KK, Kerley DM, Firman JD, Allee G.L. The effect of enzyme treatment of soybean meal on oligosaccharide disappearance and chick growth performance. Poultry Science 2002;81:1014-1019.

Junqueira LC, Carneiro J. Histologia básica. 11th ed. Rio de Janeiro: Guanabara Koogan; 2011. p. 221-253.

Leeson S, Caston L, Summers JD. Broiler response to energy or energy and protein dilution in the finisher diet. Poultry Science 1996;75:522-528.

Lehnen CR, Lovatto PA, Andretta I, Kipper M, Hauschild L, Rossi CA. Metaanalise da digestibilidade ileal de aminoácidos e minerais em suínos alimentados com rações contendo enzimas. Pesquisa Agropecuária Brasileira 2011;46(4): 438-445

Macari M, Furlan RL, Gonzáles E. Ingestão de alimentos: Mecanismos regulatórios. In: Macari M, Furlan RL, Gonzáles E. Fisiologia aviária aplicada a frangos de corte. Jaboticabal: Ed. Funep; 2002. v.2, p.187192.

Maenz DD. Enzymatic characteristics of phytases as they relate to their use in animals feeds. In: Bedford MR, Partridge GG, editor. Enzymes in farm animal nutrition. Walling fordab Publishing; 2001. p.60-84.

Manual de manejo de Frangos de corte. Guapiaçú: Cobb Vantrans; 2009. $70 p$.

Nelson TS, Walker AC. The biological evaluation of phosphorus compounds: A summary. Poultry Science 1964;43:94-98.

Oliveira MC, Marques RH, Gravena RA, Traldi AB, Godoy CR, Moraes VMB. Fitase em rações com níveis reduzidos de fósforo não-fítico para frangos de corte. Biotemas 2009;22(4):169-176.

Oluyinka AO, Cowieson AJ, Adeola O. Energy utilization and growth performance of broilers receiving diets supplemented with enzymes containing carbohydrase or phytase activity individually or in combination. British Journal of Nutrition 2007;99:682-690.
Pang $Y$, Applegate TJ. Effects of dietary copper supplementation and copper source on digesta $\mathrm{pH}$, calcium, zinc, and copper complex size in the gastrointestinal tract of the broiler chicken. Poultry Science 2007; 86:531-537.

Penz Jr AM, Silva $A B$, Rodrigues $O$. Ácidos orgânicos na alimentação de aves. Anais da Conferência Apinco'93 de Ciência e Tecnologias Avícolas; 1993; Santos, São Paulo. Brasil. Santos: Facta; 1993. p.111. 119

Pereira R, Menten JFM, Romano GG, Silva CLS, Zavarize KC, Barbosa NAA Eficiência de uma fitase bacteriana na liberação de fósforo fítico em rações de frangos de corte. Arquivo Brasileiro de Medicina Veterinaria e Zootecnia 2012;64(1):137-144

Powell S, Bidner TD, Southern LL. Phytase supplementation improved growth performance and bone characteristics in broilers fed varying levels of dietary calcium. Poultry Science 2011;90: 604-608.

Qian H, Kornegay ET, Denbow DM. Utilization of phytate phosphorus and calcium as influenced by microbial phytase, cholecalciferol, and the calcium: total phosphorus ratio em broiler diets. Poultry Science $1997 ; 76: 37-46$

Reece WO, Swenson MJ. 2006. Composição e funções do sangue. In: Swenson MJ, Reece WO. DUKES fisiologia dos animais domésticos. 12th ed. Rio de Janeiro: Guanabara Koogan; 2006. p. $24-48$

Reis CVS, Penna FJ, Oliveira MC, Roquete MLV. Glicogenose tipo I. Jornal de Pediatria 1999;75(4): 227-236

Riedesel DH. O coração: Estrutura macroscopica e propriedades básicas. In Dukes, Reece, WO, editor. Fisiologia dos animais domésticos 12.ed: Rio de Janeiro: Guanabara Koogan; 2006. p. 173-186.

Rosário MF, Da Silva MAN, Coelho AAD, Savino VJM. Síndrome ascite em frangos de corte: uma revisão sobre a fisiologia, avaliação e perspectiva. Ciência Rural 2004;34(6):1987-1996.

Schoulten NA, Teixeira AS, Conte AJ, Silva HO, Bertechini AG, Fialho ET. Efeito dos níveis de cálcio da ração suplementada com fitase sobre a deposição de minerais na tíbia de frangos de corte de 22 a 42 dias de idade. Ciência e Agrotecnologia. 2003;27:(1) 206 - 210.

Rostagno HS, Albino LFT, Donzele JL, Gomes PC, Oliveira RF, Lopes DC, Ferreira AS, Barreto LST, Euclides RF. Tabelas brasileiras para aves e suínos: composição de alimentos e exigências nutricionais. $3^{\mathrm{a}} \mathrm{ed}$ Viçosa: Universidade Federal de Viçosa; 2011. 252p.

Selle PH, Ravindran V. Microbial phytase in poultry nutrition. Animal Feed Science Technology 2007;135:1-41.

Slominski BA. Recent advances in research on enzymes for poultry diets (Review). Poultry Science 2011;90: 2013-2023.

Steiner T, Mosenthin R, Fundis A, Jakob S. Influence of feeding on apparent total tract digestibility of phosphorus and calcium in pigs fed lowphosphorus diets supplemented with microbial or wheat phytase. Livestock Science 2006;102:1 -10.

Temprano JL, Bretón I, Zugasti A, Cuerda C, Camblor M, Pérez-Diaz MD, Garcia P Hipofosfatemia grave tras el inicio de nutrición parenteral en una paciente con fistula intestinal. Nutición Hospitalaria 2004;19(4):243-247.

Vieites FM, Fraga AL, Moraes GHK, Vargas Junior JG, Nalon RP, Correa GSS, Nunes RV. Cálcio, fósforo e proteína total no sangue de frangos de corte em função de níveis de balanço eletrolítico da ração. Arquivo Brasileiro de Medicina Veterinária e Zootecnia. 2011;63:(4) 887-894

Viveros A, Brenes A, Arija I, Centeno C. Effects of mcrobial phytase supplementation on mineral utilizatio and sérum enzyme activities in broiler chicks fed different levels of phosphorus. Poultry Science 2002:81:1172-1183.

Walk CL, Addo-Chidie EK, Redford MR, Adeola O. Evaluation of a highly soluble calcium source and phytase $\mathrm{n}$ the diets of broiler chickens. Poultry Science 2012;91:2255-2263. 